\title{
Role Model: Kunal Saha
}

\author{
The Ohio based HIV specialist and researcher tells Adrian O'Dowd how he has fought against \\ medical negligence cover-ups and healthcare corruption in his home country of India
}

\section{Adrian O’Dowd}

London, UK

Kunal Saha says that being a good doctor should also mean being a good person. Originally from India, Saha is a private consultant in HIV and AIDS in Columbus, Ohio, and has been an adjunct professor at Columbus State Community College since 2007.

After qualifying in 1982 from Calcutta University, Saha migrated to the US in 1985. At that time, HIV and AIDS were becoming a significant health problem. "When I graduated, we had just started to learn about HIV, and I developed an interest and wanted to learn more," he says. "That's why, when I came to the US, I started to work on HIV and joined the University of Texas."

Saha completed a PhD from University of Texas in 1993 and did a postdoctoral fellowship at Columbia University in New York. He then joined Ohio State University as an assistant professor in 1998 to conduct research on HIV and AIDS.

Apart from his academic accomplishments, one of Saha's most important achievements has been the creation of a humanitarian organisation called People for Better Treatment (PBT) India in 2001, which is dedicated to eradicating medical corruption in the country.

The idea came after Saha's wife Anuradha, aged only 36, died following a drug allergy while the couple was visiting India in 1998. Anuradha was treated by a senior physician in Kolkata who gave her too high a dose of the wrong steroid which led to her death.

Saha filed a medical malpractice suit against the doctors involved. In 2009 the Supreme Court of India held that there had been medical negligence. The court found the four doctors and the Advanced Medicare Research Institute in Kolkata guilty of negligent treatment causing death.
The courts later awarded Saha the equivalent of around $\$ 2 \mathrm{~m}$ $(£ 1.6 \mathrm{~m} ; € 1.8 \mathrm{~m})$ and he decided to use it for the promotion of better healthcare in India. Since then, PBT India has fought for many other families that have experienced medical negligence and tackled medical corruption in the country.

"I was completely devastated when my wife died but I realised that this kind of medical negligence was rampant in India," says Saha. "People were dying because there was no accountability for negligent doctors.

"The situation was really bad then, but it has started to change and we're trying to spread public awareness about patients' rights and doctors' responsibilities. Things are different today but it is a very long journey."

\section{Nominated by David Berger}

"Kunal Saha has campaigned tirelessly against medical negligence cover-ups and healthcare corruption since 1998 when his wife died as a result of gross medical negligence in Kolkata.

His humility and relentless pursuit of doing what is right on behalf of the people of India against a famously corrupt medical and judicial establishment has been a huge source of inspiration to me. He also was of practical help in my unsuccessful attempt to get Ketan Desai removed as World Medical Association president in 2016-17.

Saha is the archetype of the humble, good person as opposed to so many people in positions of power in the medical establishment in India and elsewhere who seem more intent on furthering their own ends than representing the good of the people or the profession."

David Berger is a doctor at Broome Hospital in Western Australia

Nominate a role model: To nominate someone who has been a role model during your medical career, send their name, job title, and the reason for your nomination to arimmer@bmj.com

Published by the BMJ Publishing Group Limited. For permission to use (where not already granted under a licence) please go to http://group.bmj.com/group/rights-licensing/ permissions 